\title{
Detection and diversity evaluation of tetracycline resistance genes in grassland-based production systems in Colombia, South America
}

\author{
Johanna Santamaría ${ }^{1}{ }^{*}$, Liliana López $^{1}$ and Carlos Yesid Soto ${ }^{2}$ \\ 1 Environmental Microbiology Laboratory, Department of Biology and Environmental Sciences, University Jorge Tadeo Lozano, Bogotá, Colombia \\ 2 Department of Chemistry, National University of Colombia, Bogotá, Colombia
}

Edited by:

Rustam I. Aminov, University of Aberdeen, UK

\section{Reviewed by:}

Henning Sørum, Norwegian School of Veterinary Science, Norway

Ludek Zurek, Kansas State University, USA

Carlos F. Amábile-Cuevas, Fundación

Lusara, Mexico

\section{*Correspondence:}

Johanna Santamaría, Laboratorio de Microbiología Ambiental,

Departamento de Biología y Ciencias Ambientales, Universidad Jorge Tadeo Lozano, Carrera 4 No. 22-61, Módulo $7^{a}$, piso cuarto, Bogotá, Colombia. e-mail: johanna.santamaria@ utadeo.edu.co

\begin{abstract}
Grassland-based production systems use $\sim 26 \%$ of land surface on earth. However, there are no evaluations of these systems as a source of antibiotic pollution. This study was conducted to evaluate the presence, diversity, and distribution of tetracycline resistance genes in the grasslands of the Colombian Andes, where administration of antibiotics to animals is limited to treat disease and growth promoters are not included in animals' diet. Animal (ruminal fluid and feces) and environmental (soil and water) samples were collected from different dairy cattle farms and evaluated by $P C R$ for the genes tet $(M)$, tet $(\mathrm{O})$, tet $\mathrm{B}(\mathrm{P})$, tet $(\mathrm{Q})$, tet $(\mathrm{W})$, tet $(\mathrm{S})$, tet $(\mathrm{T})$, otr $(\mathrm{A})$, which encode ribosomal protection proteins (RPPs), and the genes tet $(A)$, tet $(B)$, tet $(\mathrm{D})$, tet $(\mathrm{H})$, tet $(\mathrm{J})$, and tet $(\mathrm{Z})$, encoding efflux pumps. A wide distribution and high frequency for genes tet $(\mathrm{W})$ and tet $(\mathrm{Q})$ were found in both sample types. Genes tet $(\mathrm{O})$ and tet $\mathrm{B}(\mathrm{P})$, detected in high frequencies in feces, were detected in low frequencies or not detected at all in the environment. Other genes encoding RPPs, such as tet $(\mathrm{M})$, tet $(\mathrm{S})$, and tet $(\mathrm{T})$, were detected at very low frequencies and restricted distributions. Genes encoding efflux pumps were not common in this region, and only two of them, tet (B) and tet(Z), were detected. DGGE-PCR followed by comparative sequence analysis of tet $(\mathrm{W})$ and tet $(\mathrm{Q})$ showed that the sequences detected in animals did not differ from those coming from soil and water. Finally, the farms sampled in this study showed more than $50 \%$ similarity in relation to the tet genes detected. In conclusion, there was a remarkable presence of tet genes in these production systems and, although not all genes detected in animal reservoirs were detected in the environment, there is a predominant distribution of tet $(\mathrm{W})$ and tet $(\mathrm{Q})$ in both animal and environmental reservoirs. Sequence similarity analysis suggests the transmission of these genes from animals to the environment.
\end{abstract}

Keywords: antibiotic resistance, cattle farms, Colombian Andes, environmental pollution, grasslands, tetracycline

\section{INTRODUCTION}

Antibiotics are broadly used around the world in concentrated animal feeding operations (CAFOs), not only to prevent and control diseases but also to promote faster growth by mixing antibiotics with livestock feed. These practices help reduce production costs and retail prices to consumers. Nonetheless, the formation of antibiotic resistant microbial pools in animal guts as a result of antibiotic administration (Aminov et al., 2001; Aarestrup, 2005; Sawant et al., 2007) is well documented. These pools have been identified as the source of many antibiotic resistant pathogenic bacteria transmitted to humans (van den Bogaard and Stobberingh, 2000), and the consumption of meat, meat-derived products, eggs, and food contaminated with antibiotic resistant zoonotic bacterial pathogens, is considered the most common transmission route of antibiotic resistance from animal farms to humans (Aarestrup, 2006).

An emergent concern is that antibiotic resistance could be transmitted from environmental resistance reservoirs to humans and animal pathogens by consuming polluted water or agricultural food products. Environmental reservoirs of resistance may be the result of three different process: the selective pressure exerted by the antibiotics released in animal waste (Winckler and Grafe, 2001; Campagnolo et al., 2002), the horizontal gene transfer between the resistant bacteria released in feces and indigenous bacteria (Götz and Smalla, 1997; Witte, 2000; Sengelov et al., 2003; Schwarz et al., 2006; Heuer and Smalla, 2007; Binh et al., 2008), and finally, natural selective pressures on the microbial community (Aminov, 2009; Martinez, 2009). Previous studies conducted in United States and Europe have shown the presence of tetracycline resistance pools in surface and ground water of industrial livestock facilities proving that CAFOs and land application of manure are important sources of environmental antibiotic pollution that promote environmental reservoirs of resistance (Aminov et al., 2001; Chee-Sanford et al., 2001; Koike et al., 2007; Patterson et al., 2007; Peak et al., 2007; Knapp et al., 2010; Heuer et al., 2011). 
Unlike industrial facilities, grassland-based production systems rely upon natural vegetation growing in the field for feeding animals that live off the land, with low numbers of livestock units per area. The administration of antibiotics is restricted to disease control, and no food concentrates containing antibiotics are used. However, even though the amount of antibiotics administered to animals in grasslands is significantly lower to the amount administered in CAFOs, the possibility of animal and environmental reservoirs of resistance, as a result of the livestock activity in these extensive production systems, cannot be ruled out. It has been demonstrated the presence of resistant bacteria in animals when no growth promoters have been administered (Blake et al., 2003; Bryan et al., 2004; Alexander et al., 2008). Despite the fact that grasslands represent $\sim 26 \%$ of the land surface on earth (Steinfeld et al., 2006), there are no evaluations of grassland-based systems as a source of antibiotic pollution.

The first objective of the present study was to evaluate the presence, distribution, and diversity of microbial genes encoding resistance to the antibiotic tetracycline in animal (ruminal fluid and feces) and environmental (soil and water) samples from grasslandbased systems located in the tropical highlands of Colombia. The presence of resistance in the total microbial community, including viable but non-culturable bacteria, was evaluated by PCR detection of the genes tet $(\mathrm{M}), \operatorname{tet}(\mathrm{O}), \operatorname{tet} \mathrm{B}(\mathrm{P})$, tet $(\mathrm{Q})$, tet $(\mathrm{W})$, tet $(\mathrm{S})$, tet $(\mathrm{T})$, $\operatorname{otr}(\mathrm{A})$, which encode ribosomal protection proteins (RPPs), and the genes tet $(\mathrm{A})$, tet $(\mathrm{B})$, tet $(\mathrm{D})$, tet $(\mathrm{H})$, tet $(\mathrm{J})$, and tet $(\mathrm{Z})$, encoding tetracycline efflux pumps (Roberts, 2005). Tetracycline resistance was chosen because this antibiotic is frequently used in Colombia and other regions of the world for veterinary purposes. In addition, no antibiotic resistance evaluations of the total microbial community at the animal and environmental levels have been previously conducted in Latin America and the Caribbean Region, where grassland animal production is one of the most important economic activities (FAO, 2008). The second objective of this study was to establish whether the tet genes found in the environment of the highlands were part of an intrinsic resistance in the indigenous bacteria community or originating from the animal reservoirs in the region.

\section{MATERIALS AND METHODS STUDY SITE}

This study evaluated six different grassland-based cattle farms, mainly used for milk production: Manitas, Puente Luna, Granada, Lindaraja, Alisos, and Corpoica. These sites are located on the Eastern Cordillera of the Colombian Andes in a high plateau known as Altiplano Cundiboyacense (Figure 1). The administration of antibiotics to animals on these farms is limited to the treatment of health problems. This limitation is part of a strict management because the milk produced in the highlands of Colombia is purchased by the dairy industry, and when traces of antibiotics are

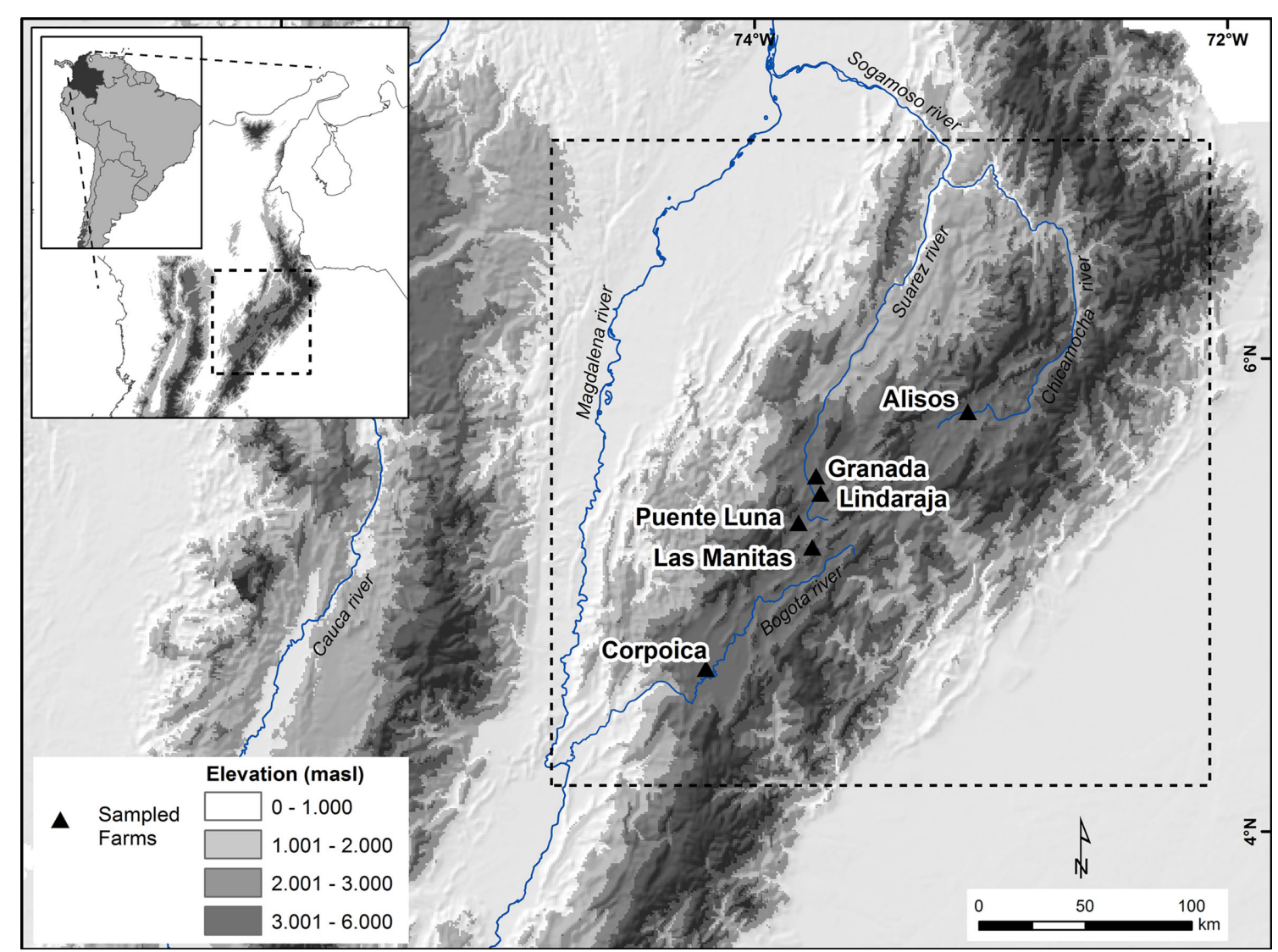

FIGURE 1 | Locations of the sampling sites at the Altiplano Cundiboyacense, Colombian Andes. 
found, the milk is rejected. In addition, many farms belong to small producers who cannot pay the high cost of the drugs used in this region.

The most often administered antibiotic in these farms is the oxytetracycline dehydrate, followed by the ampicillin. Unfortunately, farms managers do not keep record of dose and frequency of use. Nonetheless, based on data supplied by veterinarians working for these extensive production systems, it was estimated that the evaluated farms, with a number of animals between 60 and 100 , use approximately between 13 and $130 \mathrm{~g}$ of oxytetracycline dihydrate in a week. These values are well below the estimated $9 \mathrm{~kg}$ of chlortetracycline used per week in a medium size intensive Colombian pig farm with 3000 animals.

\section{SAMPLE COLLECTION}

One sampling event was conducted at each farm where soil, water, feces, and ruminal fluid samples were collected.

Soil samples were collected from two different plots under the influence of cattle waste. At each plot, four composite samples were obtained, each resulting from four pooled soil cores. The soil cores were randomly taken from the surface $(0-5 \mathrm{~cm})$ along four transects $\sim 5 \mathrm{~m}$ apart and $10 \mathrm{~m}$ long.

Four composite feces samples were collected at one of the plots, according to the sampling design described for soils. For this sampling, $50 \mathrm{~g}$ of feces were taken from the inner center of a fresh cow pie at each sampling point.

Runoff, ground, and animal drinking water samples were collected depending on their availability at the sites. In all farms, except Manitas, $50 \mathrm{ml}$ samples of runoff water were collected from a ditch draining system. In Manitas, runoff water samples were collected from a pond where waters collect and remain stagnant. To obtain the samples, a 50-ml sterile container was submerged about $50 \mathrm{~cm}$ below the water surface at different locations around the waterbody. Animal drinking water samples had different sources depending on the farm. In Puente Luna and Corpoica, animal drinking water is the same potable water consumed by the human population and is supplied by a municipal water processing plant. In Granada, Lindaraja, and Alisos, animal drinking water is in situ chemically treated runoff water. Approximately $100 \mathrm{ml}$ of this water was collected from cattle troughs in a sterile container. The groundwater samples from active farming wells were collected from the valve system installed at the head of each well. Water ran for $30 \mathrm{~min}$ before filling a sterile $150 \mathrm{ml}$ glass bottle.

Approximately $100 \mathrm{ml}$ of ruminal fluid was collected from each animal using a bovine esophageal probe.

All samples were stored in a refrigerated cooler, transported to the laboratory, and processed within $24 \mathrm{~h}$. The number of collected samples per farm and the number of samples analyzed are listed in Table 1.

\section{DNA EXTRACTION}

Total DNA was extracted in duplicate from $0.5 \mathrm{~g}$ of each soil and feces composite samples and from $0.5 \mathrm{ml}$ of each ruminal fluid sample. DNA isolation was performed using the Ultra Clean DNA kit from Mo Bio Laboratories Inc., according to manufacturer's instructions with modifications. Briefly, samples in the bead solution tubes containing SDS were boiled in water for $10 \mathrm{~min}$ before proceeding with the protocol. Subsequently, an equal volume of phenol was added to remove excess organic matter present in the samples previously treated with the protein precipitation reagent. After separating the phenol/aqueous phases by centrifugation, the aqueous phase was mixed with the DNA binding salt solution and passed through the silica membrane of the spin filter. Samples were resuspended in $50 \mu \mathrm{l}$ of the elution buffer $(10 \mathrm{mM}$ Tris Buffer, $\mathrm{pH}$ 8.5) and stored at $-20^{\circ} \mathrm{C}$.

For DNA extraction, 50, 100, and $150 \mathrm{ml}$ samples of runoff, animal drinking, and ground water, respectively, were filtered through a $25-\mathrm{mm}$ polyester sulfone membrane with a $0.22-\mu \mathrm{m}$ pore size (Supor 200, Pall Corporation). Subsequently, the membranes were cut into small squares of approximately $5 \mathrm{~mm} \times 5 \mathrm{~mm}$, and the DNA was extracted with the Mo Bio kit as described previously, except the phenol step was omitted for the groundwater samples.

\section{POLYMERASE CHAIN REACTION}

Amplification reactions were performed with a Labnet Thermal Cycler in a final reaction volume of $50 \mu \mathrm{l}$. The reaction mixtures contained 1X PCR reaction buffer, $2 \mathrm{mM} \mathrm{MgCl}_{2}, 200 \mathrm{nM}$ of each dNTP, $200 \mathrm{nM}$ of forward and reverse primers, $1 \mathrm{U}$ Taq polymerase (Promega), $400 \mathrm{ng} / \mu \mathrm{l}$ BSA (Bioline), and $1 \mu \mathrm{l}$ of DNA solution. The following basic thermocycling program was used for all the PCR reactions: $94^{\circ} \mathrm{C}$ for $4 \mathrm{~min}(1 \mathrm{cycle}) ; 94^{\circ} \mathrm{C}$ for $50 \mathrm{~s}, \mathrm{X}^{\circ} \mathrm{C}$ for $40 \mathrm{~s}$, and $72^{\circ} \mathrm{C}$ for $30 \mathrm{~s} \mathrm{(30} \mathrm{cycles);} 72^{\circ} \mathrm{C}$ for $4 \mathrm{~min}$. The annealing temperature $(\mathrm{X})$ was specific for each primer pair used to amplify the genes encoding for RPPs and tetracycline efflux pumps. Primers details and annealing temperatures are described in Aminov et al. (2001) and Aminov et al. (2002). DNA fragments of 250 bp, containing annealing sequences for tet genes, were synthesized by DNA Technologies, Inc., San Diego, CA, USA and used as positive controls. The control sequences were obtained from Aminov et al. (2001, 2002). Negative controls were also included in each PCR reaction. Before testing isolated DNA with tet primers, the DNA quality was assessed by performing an initial amplification with the $16 \mathrm{~S}$ rDNA universal Bacteria primers $8 \mathrm{~F}$ and $1541 \mathrm{R}$ using PCR conditions described by Loffler et al. (2000).

To assess the similarity among sampled farms in terms of presence and frequency of the detected tet genes, a cluster analysis was conducted based on the percentage similarity index and the UPGMA method of hierarchical agglomeration using the XLSTAT 6.0 software (Addinsoft, NY, USA, 20011).

\section{DENATURING GEL ELECTROPHORESIS ANALYSIS AND SEQUENCING OF AMPLIFIED REGIONS}

Animal and environmental DNA samples that were positive for two of the most frequent genes were selected for PCR-Denaturing gel electrophoresis analysis (DGGE). Positive tet samples were newly amplified by PCR using a forward primer with a GC tail (Kobayashi et al., 2007). PCR conditions were the same as described before. The Bio-Rad D-Code Universal Mutation System was used to analyze the polymorphisms found in these PCR products by loading $30 \mu \mathrm{l}$ on an $8 \%$ polyacrylamide/bis acrylamide $37.5: 1$ gel in $1 \mathrm{X}$ TAE. The denaturing gradient was $30-50 \%$, and the electrophoresis was performed for $18 \mathrm{~h}$ at $40 \mathrm{~V}$ and $60^{\circ} \mathrm{C}$. To visualize the DNA, gels were stained in ethidium bromide solution 
Table 1 | PCR evaluation results for the presence of tet genes in the samples collected from each farm sampled.

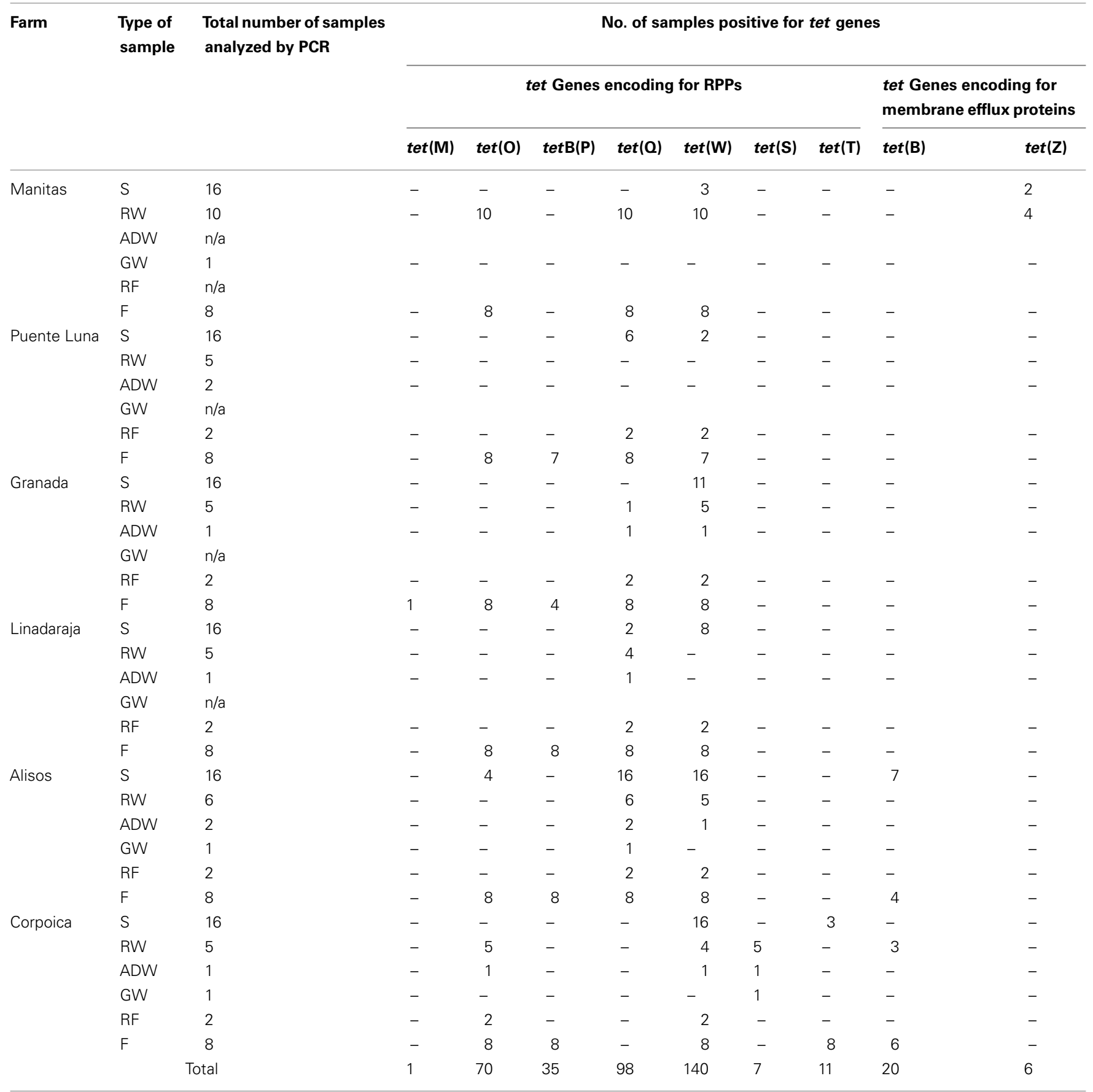

$S$, soil; RW, runoff water; $A D W$, animal drinking water; GW, ground water; $R F$, ruminal fluid; $F$, feces; -, there were no positive samples for the gene; $n / a$, not available sample.

$(5 \mu \mathrm{g} / \mathrm{ml})$, and digital images were taken using a UVP Gel Doc-It ${ }^{\mathrm{TM}}$ system.

Denaturing gel electrophoresis analysis bands were sequenced to confirm the identity of the amplified products and to compare which PCR products originated from animal and environmental samples. For the analysis, bands were excised from the gel and stored in distilled water for $12 \mathrm{~h}$. Water containing the diffused template was used for PCR, and the reamplification products were sequenced using a DYEnamic ET Dye terminator kit (MegaBACE) on a MegBACE 1000 (GE Amersham) sequencer.

The identity of PCR amplicons was confirmed by comparing nucleotide sequences with the Gene Bank Database at National Center for Biotechnology (NCBI) using the basic logical alignment search tool (BLAST). Sequence alignment and cluster analysis, 
including the tet genes from animal and environmental origin detected in the present study and other studies, were performed with Sequencher 4.1 and Clustal W.

\section{RESULTS}

\section{DETECTION OF TETRACYCLINE RESISTANCE GENES}

All of the farms evaluated were positive for tet genes in both animal and environmental samples (Table 1 ). The detected genes include tet $(\mathrm{W}), \operatorname{tet}(\mathrm{Q}), \operatorname{tet} \mathrm{B}(\mathrm{P}), \operatorname{tet}(\mathrm{O}), \operatorname{tet}(\mathrm{M}), \operatorname{tet}(\mathrm{S}), \operatorname{tet}(\mathrm{T})$, tet $(\mathrm{B})$, and tet $(\mathrm{Z})$. The genes $\operatorname{otr}(\mathrm{A})$, tet $(\mathrm{A}), \operatorname{tet}(\mathrm{D})$, tet $(\mathrm{H})$, and tet $(\mathrm{J})$ were not detected in any sample. The highest detection frequencies were for those genes encoding RPPs with 355 out of 388 positive PCR reactions. Among this group, the most frequent were tet (W) with $36 \%$ (140 out of 388), tet (Q) with $25 \%$ (98 out of 388), and tet $(\mathrm{O})$ with $18 \%$ (70 out of 388; Table 2 ).

Considering the frequency of detection per sample type, feces and ruminal fluid showed the highest frequencies of PCR positives for tet genes. Specifically, tet $(\mathrm{O})$, tet $(\mathrm{W})$, tet $(\mathrm{Q})$, and tet $\mathrm{B}(\mathrm{P})$ were present in $100,98,83$, and $70 \%$ of the feces samples, respectively (Table 2), while tet (W) and tet(Q) with frequencies of 100 and $80 \%$, respectively, were the most common genes detected in the ruminal fluid. Genes tet $(\mathrm{T})$ and tet $(\mathrm{B})$ were also detected in feces, although with low frequencies.

Generally, tet $(\mathrm{W})$ and tet $(\mathrm{Q})$ were detected simultaneously in feces and runoff water samples from the farms, except in Lindaraja and Puente Luna. In Lindaraja, tet (W) was detected only in feces, while in Puente Luna both genes were found only in the feces samples (Table 1). Of all the genes that were detected simultaneously in feces and runoff water, only tet $(\mathrm{W})$ and tet $(\mathrm{Q})$ were present in soil samples at relatively high frequencies (Table 2 ). Treated runoff water, used as animal drinking water in Granada, Lindaraja, and Alisos, tested positive for the most common genes tet (W) and tet $(\mathrm{Q})$. Resistance was not detected in animal drinking water from the municipal processing plant in Puente Luna; however, tet $(\mathrm{W})$, tet $(\mathrm{S})$, and tet $(\mathrm{O})$ were detected in the samples from Corpoica
(Table 1). Of the three groundwater samples analyzed, the samples collected from Granada and Corpoica were positive only for genes tet $(\mathrm{Q})$ and tet $(\mathrm{S})$, respectively.

An analysis of the gene patterns detected per reservoir type (Table 3) revealed that in four of the six sampled farms, the tet gene diversity was higher in animal samples as compared with the environmental samples. We also observed that the $\operatorname{tet} \mathrm{B}(\mathrm{P})$ gene was only found in animal samples, and in the contrast, the genes tet $(\mathrm{S})$ and tet $(\mathrm{Z})$ were only found in environmental samples, although at low frequencies (Table 2).

Cluster analysis shows that the geographically closest sites, Puente Luna, Lindaraja, and Granada, are significantly more similar in relation to the genes detected and their frequencies (Figures 1 and 2). Manitas is more distant from this group because the gene tet $(\mathrm{Z})$ was detected at this site but not tet $(\mathrm{B} / \mathrm{P})$. Corpoica is less similar with the other sites due to the absence of gene tet $(\mathrm{Q})$ and the presence of genes tet $(\mathrm{S})$. The tet $(\mathrm{B})$ gene was not detected in the other sampling sites.

\section{DGGE AND SEQUENCE ANALYSIS}

Denaturing gel electrophoresis analysis results did not show genetic polymorphisms for tet $(\mathrm{W})$ amplicons from any farm sampled. Sequences originating from both, animals and environment, exhibited a single band at the same gel level (data not shown). Blast analysis confirmed that the sequences of the bands corresponded to gene tet $(\mathrm{W})$, and the alignment analysis showed no difference among the sequences from the samples, including the positive control, B. fibrisolvens (Nikolich et al., 1992). In addition, Clustal W analysis confirmed that the tet $(\mathrm{W})$ sequences reported in this study had $100 \%$ identity with more than $83 \%$ of counterpart tet $(\mathrm{W})$ sequences reported in databank.

In contrast, DGGE patterns for gene tet(Q) amplicons showed several bands per sample (data not shown). Blast analysis confirmed that sequences of all the bands observed corresponded to gene tet $(\mathrm{Q})$, and the alignment analysis showed that most of

Table 2 | PCR evaluation results for the presence of tet genes in animal and environmental samples.

\begin{tabular}{|c|c|c|c|c|c|c|c|c|c|c|c|}
\hline \multirow{3}{*}{$\begin{array}{l}\text { Sample } \\
\text { type }\end{array}$} & \multirow{3}{*}{$\begin{array}{l}\text { No. of samples } \\
\text { evaluated by PCR }\end{array}$} & \multicolumn{9}{|c|}{ No. of samples positive for tet genes } & \multirow{3}{*}{$\begin{array}{l}\text { Total PCR } \\
\text { reactions }\end{array}$} \\
\hline & & \multicolumn{7}{|c|}{ tet Genes encoding RPPs } & \multicolumn{2}{|c|}{$\begin{array}{l}\text { tet Genes encoding } \\
\text { efflux pumps }\end{array}$} & \\
\hline & & tet(M) & $\operatorname{tet}(0)$ & tet $\mathrm{B}(\mathrm{P})$ & $\operatorname{tet}(\mathrm{Q})$ & $\operatorname{tet}(\mathrm{W})$ & $\operatorname{tet}(\mathrm{S})$ & $\operatorname{tet}(\mathrm{T})$ & $\operatorname{tet}(\mathrm{B})$ & $\operatorname{tet}(\mathrm{Z})$ & \\
\hline RW & 36 & - & $15(42)$ & - & $21(58)$ & $24(67)$ & $5(14)$ & $3(38)$ & $3(8)$ & $4(11)$ & 75 \\
\hline ADW & 7 & - & $1(14)$ & - & $4(57)$ & $3(43)$ & $1(14)$ & - & - & - & 9 \\
\hline GW & 3 & - & - & - & $1(33)$ & - & $1(33)$ & - & - & - & 2 \\
\hline \multicolumn{12}{|c|}{ ANIMAL } \\
\hline $\begin{array}{l}\mathrm{RF} \\
\mathrm{F}\end{array}$ & 10 & - & $2(20)$ & - & $8(80)$ & $10(100)$ & - & - & - & - & 20 \\
\hline
\end{tabular}

(), Frequency of detection = No. of samples positive for a given gen/total number of evaluated samples* 100.

-, There were no positive samples for the gene; $S$, soil; RW, runoff water; ADW, animal drinking water; GW, ground water; RF, ruminal fluid; $F$, feces. 
the bands in a sample shared the same sequence. We observed a maximum of two bands with different tet $(\mathrm{Q})$ genotypes within a sample. The multiple bands for the same sequence in the DGGE patterns of tet $(\mathrm{Q})$ probably resulted from the presence of singlestranded DNA and the formation of a PCR product with multiple denaturation domains (Kocherginskaya et al., 2001; Kobayashi et al., 2007; Calabria de Araujo and Schneider, 2008). Cluster analysis classified 70 of the tet $(\mathrm{Q})$ band sequences observed in the DGGE analysis into five different groups based on nucleotide variations, rather than the sample type (Figure 3). Only five different genotypes were found, which differed at position 32, where a thymine had been replaced by cytosine and also at position 65 where a thymine was replaced by adenine or guanine as compared with the positive control B. thetaiotaomicron (Aminov et al., 2001). There were no particular tet $(\mathrm{Q})$ genotypes associated exclusively

Table 3 | Gene patterns detected in the animal and environmental samples from each sampled farm.

\begin{tabular}{lll}
\hline Farm & \multicolumn{2}{c}{ Type of sample } \\
\cline { 2 - 3 } & Animal & \multicolumn{1}{c}{ Environmental } \\
\hline Manitas & tet $(\mathrm{O}),(\mathrm{Q}),(\mathrm{W})$ & $\operatorname{tet}(\mathrm{O}),(\mathrm{Q}),(\mathrm{W}),(\mathrm{Z})$ \\
Puente Luna & tet $(\mathrm{O}),(\mathrm{Q}),(\mathrm{W}), \mathrm{B}(\mathrm{P})$ & tet $(\mathrm{Q}),(\mathrm{W})$ \\
Granada & tet $(\mathrm{O}),(\mathrm{Q}),(\mathrm{W}), \mathrm{B}(\mathrm{P}),(\mathrm{M})$ & tet $(\mathrm{Q}),(\mathrm{W})$ \\
Lindaraja & tet $(\mathrm{O}),(\mathrm{Q}),(\mathrm{W}), \mathrm{B}(\mathrm{P})$ & tet $(\mathrm{Q}),(\mathrm{W})$ \\
Alisos & tet $(\mathrm{O}),(\mathrm{Q}),(\mathrm{W}), \mathrm{B}(\mathrm{P}),(\mathrm{B})$ & tet $(\mathrm{O}),(\mathrm{Q}),(\mathrm{W}),(\mathrm{B})$ \\
Corpoica & tet $(\mathrm{O}),(\mathrm{W}), \mathrm{B}(\mathrm{P}),(\mathrm{B}),(\mathrm{T})$ & tet $(\mathrm{O}),(\mathrm{W}),(\mathrm{B}),(\mathrm{T}),(\mathrm{S})$
\end{tabular}

with the environmental or animal samples for groups two, four, and five. However, group one only presented sequences detected in environmental samples, although these sequences grouped together with the control, which is a sequence of clinical origin (Figure 3). Notably, most sequences were included in Group 5, which was characterized by nucleotide changes at positions 32 and 65 , where the thymine was replaced by an adenine. These changes were also observed in tet $(\mathrm{Q})$ nucleotide sequences previously reported (Aminov and Mackie, 2007). According to Clustal and Generunner analyses, these mutations do not produce changes in the protein sequence when they are compared with the Tet $(Q)$ protein of the reference strain B. thetaiotaomicron; in both positions, the amino acid glycine is conserved.

\section{DISCUSSION}

Assessing the presence of resistance genes to the antibiotic tetracycline in the highlands of Colombia has revealed not only resistance reservoirs in dairy cattle raised in this region but also a wide distribution of tet genes in the environment of grasslandbased production systems. The detection frequency and spatial distribution of resistance genes in the runoff water and soils was remarkable, especially for genes tet $(\mathrm{W})$ and tet $(\mathrm{Q})$. It is known that resistant bacteria occur in nature as a result of natural selective pressures (Aminov, 2009; Martinez, 2009), as it was shown by some studies reporting tetracycline resistance in a national park and in fecal bacteria of wild animals in areas which apparently are not under the exposure of urban or agricultural antibiotic contamination (Gilliver et al., 1999; Yang et al., 2010; Rahman et al., 2008).

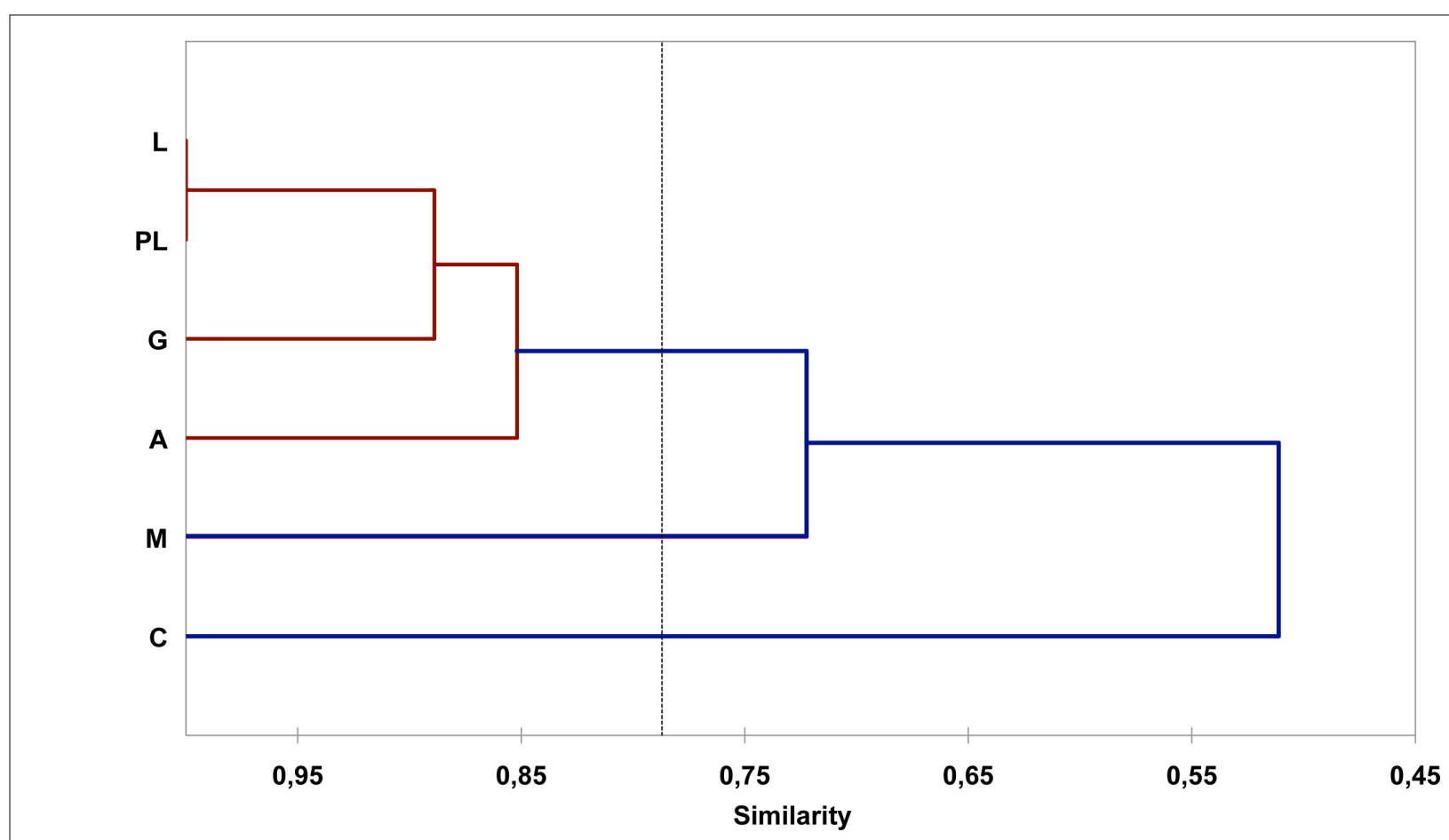

FIGURE 2 | Cluster analysis (UPGMA, percentage similarity index) for farms sampled, based on the presence and frequency of tet genes. M, Manitas; PL, Puente Luna; G, Granada; L, Lindaraja; A, Alisos; C, Corpoica. 


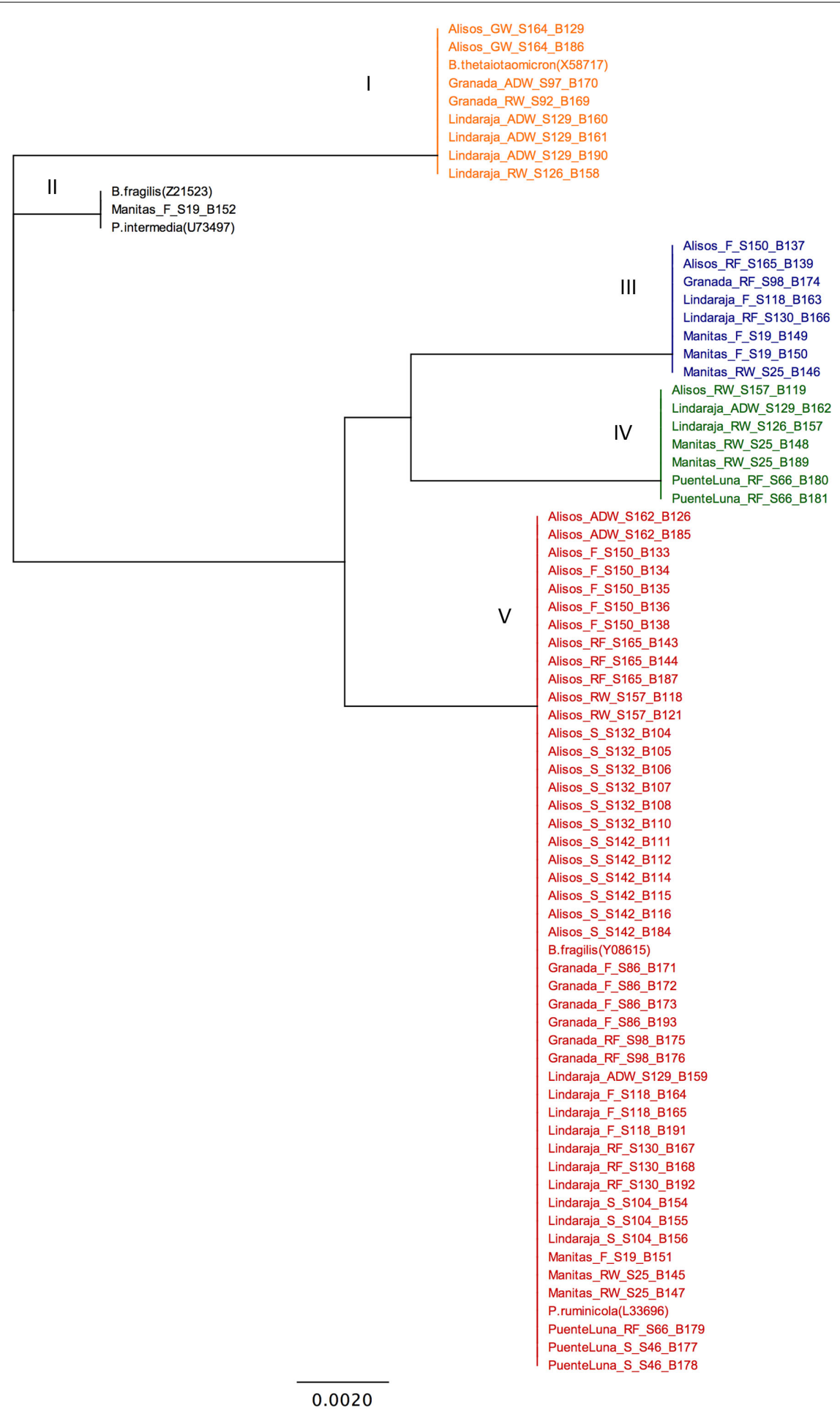

FIGURE 3 | Unrooted phylogram showing the genetic distances among gene tet(Q) sequences (neighbor-joining). $S_{-}$, soil; RW, runoff water; $A_{D} W_{-}$, animal drinking water; GW_, ground water; RF, ruminal fluid; $F_{-}$, feces, S, Sample ID; B, DGGE band sequence ID.

However, tet genes detected in the evaluated grasslands-based production systems in Colombia, do not seem to be the result of natural selective pressures. Instead, they are probably the result of horizontal gene transfer because, the same tet (W) and tet (Q) sequences were detected in animal, soil, and water samples. Additionally, it was not found any novel sequence for these genes at the Altiplano region. Sequences detected for these genes did not differ from most of the tet $(\mathrm{Q})$ and tet $(\mathrm{W})$ sequences reported in 
the literature. It was not feasible to include in this study plots of grazing land free areas in order to compare samples of natural environments with those samples collected in the active grazing plots. The vast majority of the land in the Altiplano Cundiboyacense is (or had been during the last decades) under the influence of cattle waste given the predominant extensive cattle production system. Therefore, it was not possible to determine the presence and frequency of the tet genes in an environment of the Altiplano that is not under the exposure of antibiotic contamination.

Cattle raised in the grassland-based production systems at the highlands of Colombia, seem to be a source of tetracycline resistance genes into the environment, especially those coding for RPPs. This transmission was concluded on the basis that detection frequencies for genes $\operatorname{tet}(\mathrm{Q})$ and $\operatorname{tet}(\mathrm{W})$ in the digestive tract of the animals sampled in this region was greater than $80 \%$, and these genes were also common in the environmental samples, especially in water. Moreover, the sequences of the genes tet (W) and tet $(\mathrm{Q})$ detected in soil and water did not differ from those found in samples of animal origin, and no $\operatorname{otr}(\mathrm{A})$ genes were detected from antibiotic-producing bacteria. Finally, Lopez et al. (Submitted manuscript) examined the presence of tet genes and their sequences in 150 heterotrophic tetracycline resistant bacteria isolated by culture techniques from the animal and environmental samples analyzed in the present study. These data showed that a high percentage of the isolates were positive for genes tet $(\mathrm{W})$ (53)\% and tet(Q) (35\%). Gene tet (W) did not show any genetic polymorphism as it was observed for tet (W) sequences detected in the total DNA samples. Sequences of gene tet(Q) detected in the isolates, showed three different genotypes which were identical to those in group one, two, and five in Figure 3. These groups included sequences detected in bacteria isolated from both, animal and environmental samples. 16S rRNA sequences analysis of the bacteria isolates, revealed that genera where genes tet (W) and tet (Q) were detected included Enterococcus, Staphylococcus, Escherichia, Klebsiella and Shigella, and also non-strict pathogenic, non-clinical bacteria commonly found in the environment such as Burkholderia, Chryseobacterium, Variovorax, Acinetobacter, Pseudomonas, and Dyella. Therefore, based on the foregoing, it is likely that the resistance genes detected at the Altiplano Cundiboyacense originated from animal reservoirs and are neither associated with native bacteria genes that produce antibiotics nor the result of selective pressure exerted by the tetracycline released into the environment on microbial populations.

A comparison of gene patterns detected in animal and environmental samples from the Altiplano (Table 3) revealed that the detected genes are not equally distributed in animal and environmental reservoirs. Despite having a 100\% frequency of detection in feces from all the sampling sites, gene tet $(\mathrm{O})$ was not detected in environmental samples from Puente Luna, Granada, and Lindaraja. Gene tet $\mathrm{B}(\mathrm{P})$, also with high frequencies of detection in feces, was not detected in water or soil samples from any site. These results are consistent with the mobility reported for tet genes in the literature. Genes tet (W) and tet $(\mathrm{Q})$, found in 18 and 15 different bacteria genera, respectively, have high transferability rates because they are associated with conjugative chromosomal elements encoding their own transfer (Roberts, 2005). However, genes tet $(\mathrm{O})$ and $\operatorname{tet} \mathrm{B}(\mathrm{P})$, found in 10 and 1 bacteria genera, respectively, are not normally associated with conjugative transposons or other types of mobile genetic elements (Chopra and Roberts, 2001; Roberts, 2005), which could limit the flow of these genes into soil and water bacteria.

Runoff water might be playing an important role in the transmission of genes with genetic mobility to the regions of Altiplano and the north of Colombia. This transmission is possible because runoff water in the ditch systems, where samples were collected, flows into the Bogotá and Sogamoso watersheds, which in turn drain into the Magdalena River Basin (Figure 1). Considering the high detection frequencies of tet $(\mathrm{Q})$ and tet $(\mathrm{W})$ genes in runoff waters and the high rainfall precipitation throughout most of the year in this region (IDEAM, 2010) resistance genes might be dispersed by the waters of Magdalena because this river crosses the country from north to south emptying into the great slope of the Caribbean. Although this study did not analyze river water impacted by runoff, Kobayashi et al. (2007) and Tao et al. (2010) demonstrated the presence of resistance genes in waters and sediments from rivers impacted by waste coming from developed areas in southern Vietnam and China, where significant amounts of antibiotics are administrated to humans and animals.

There seems to be a geographical distribution of some tet genes in the Altiplano region. Sampled farms showed more than $50 \%$ similarity in relation to the detected tet genes and their frequencies (Figure 2), and this similarity increases with decreasing geographical distances. For instance, Puente Luna, Granada, and Lindaraja, close and under the influence of a dense hydrographic network that flows into the Sogamoso River, are significantly more similar to each other than to Corpoica, located further apart and under the influence of a different hydrographic network that flows into the Bogota River. Moreover, the presence of genes tet $(\mathrm{S})$ and tet $(\mathrm{T})$ and the absence of $\operatorname{tet}(\mathrm{Q})$ make Corpoica different from the other sites. Manitas, a farm surrounded by fewer streams per square kilometer was the only site positive for gene tet $(\mathrm{Z})$ and the only site where tet $(\mathrm{B} / \mathrm{P})$ was not detected. The differences in the geographical distribution of some tet genes might result from differences in the management practices for the administration of antibiotics. Alexander et al. (2011), showed that cattle fed with different subtherapeutic antibiotics presented different abundances of certain resistance genes. Future studies are needed to clarify how the geographical location, presence of hydrological networks, and management practices for the administration of antibiotics determines the distribution of tet genes at the highland plateau of the Altiplano Cundiboyacense.

Ruminal fluid samples did not reveal the variety of tet genes occurring in animals reservoirs as feces did. Genes tet $\mathrm{B}(\mathrm{P})$, tet $(\mathrm{T})$, and tet (B) were found in feces but not in the forestomach, may be as a result of differences in the microbial populations along the ruminant digestive tract. It has been demonstrated that rumen and feces have different microbial communities as a result of differences in the environmental conditions between rumen and the end of the digestive tract, such as $\mathrm{pH}$, degree of anaerobiosis, and available substrates (Michelland et al., 2009; Callaway et al., 2011). Therefore, genes tet $(\mathrm{W})$ and tet $(\mathrm{Q})$, reported in a wide range of genera (Roberts, 2005), are detected in bacteria associated with both rumen and the end of the intestinal tract. However, genes with narrow distribution ranges, such as tet $\mathrm{B}(\mathrm{P})$, tet $(\mathrm{T})$, 
and tet(B) (Roberts, 2005), were associated only with bacteria at the end of the intestinal tract. In fact gene tet $\mathrm{B}(\mathrm{P})$ has been only reported in Clostridium, one of the predominant genera in feces (Callaway et al., 2011). Surprisingly, tet(M), although having a wide distribution range (Roberts, 2005), was only present in feces. This gene was not common on any sampled farm at the Altiplano region; it was only detected in one feces sample from Granada. Nevertheless, we cannot rule out the presence of tet $(\mathrm{M})$ in the animal and environmental microbial community, where it might be present at a low frequency, making it difficult to detect by PCR.

Genes tet $(\mathrm{W})$, tet $(\mathrm{Q})$, and tet $(\mathrm{O})$, detected in higher frequencies at the Altiplano Cundiboyacense, were also frequently detected in studies conducted in the United States by Aminov et al. (2001) and Peak et al. (2007) for ruminal content and waste water lagoons near cattle feedlots. The most particular results found in this present study were related to the frequencies detected for genes tet $(\mathrm{M})$ and tet $\mathrm{B}(\mathrm{P})$. Specifically, tet $(\mathrm{M})$, often associated with conjugative transposons and identified in 35 genera from variety of ecosystems, including humans, animals, and soils (Roberts, 2005), was not common at the Altiplano Cundiboyacense. By contrast, in other studies, it is reported as a common gene (Peak et al., 2007; Alexander et al., 2011). Gene tet $\mathrm{B}(\mathrm{P})$, which is commonly found in the intestinal tract of cows from most sampled farms in this study, is not reported in previous studies of ruminal content, cow feces, soil amended with cow manure, or waste water lagoons near cattle feedlots conducted in Europe and the United States. Finally, the most frequent genes found in the highlands of Colombia are those encoding RPPs. Genes encoding membrane efflux pumps are neither diverse nor frequent. Conversely, Sawant et al. (2007) in the United States showed that genes tet(B) and tet(A) encoding for efflux pumps, were the tet genes most frequently found in feces of dairy cattle. Additionally, a study conducted by Kobashi et al. (2007) in various agricultural environments of Japan, showed that tet genes encoding efflux pumps were more frequent than those

\section{REFERENCES}

Aarestrup, F. M. (2005). Veterinary drug usage and antimicrobial resistance in bacteria of animal origin. Basic Clin. Pharmacol. Toxicol. 96, 271-281.

Aarestrup, F. M. (2006). “Origin, evolution and local and global dissemination of antimicrobial resistance," in Antimicrobial Resistance in Bacteria of Animal Origin, ed. F. M. Aarestrup (Washington, DC: ASM Press), 339-359.

Alexander, T. W., Yanke, J. L., Reuter, T., Topp, E., Read, R. R., Selinger, B. L., and McAllister, T. A. (2011). Longitudinal characterization of antimicrobial resistance genes in feces shed from cattle fed different subtherapeutic antibiotics. BMC Microbiol. 11, 19-30. doi:10.1186/1471-2180-11-19

Alexander, T. W., Yanke, L. J., Topp, E., Olson, M. E., Read, R. R., Mork, D. W., and McAllister, T. A. (2008). Effect of subtherapeutic administration of antibiotics on the prevalence of antibiotic resistant Escherichia coli bacteria in feedlot cattle. Appl. Environ. Microbiol. 74, 4405-4416.

Aminov, R. I. (2009). The role of antibiotics and antibiotic resistance in nature. Environ. Microbiol. 11, 2970-2988.

Aminov, R. I., Chee-Sanford, J. C., Garrides, N., Teferedegne, B., Krapac, I. J., White, B. A., and Mackie, R. I. (2002). Development, validation and application of PCR primers for detection of tetracycline efflux genes of gram negative bacteria. Appl. Environ. Microbiol. 68, 1786-1793.

Aminov, R. I., Garrigues-Jean-Jean, M., and Mackie, R. I. (2001). Molecular ecology of tetracycline resistance: development and validation of primers for detection of tetracycline resistance genes encoding ribosomal protection proteins. Appl. Environ. Microbiol. 67, $22-32$.

encoding for RPPs. As far as we know, only Yang et al. (2010), have reported in the USA that gene pools of tet $(\mathrm{O})$ and tet $(\mathrm{W})$, were bigger than those encoding efflux pumps in fecal and water samples of cattle operations.

In conclusion, grassland production systems at the highlands plateau of the Altiplano Cundiboyacense present animal and environmental reservoirs of tetracycline resistance genes, especially for genes tet $(\mathrm{W})$ and tet $(\mathrm{Q})$ encoding RPPs. The high frequency of detection of these genes in soil and water is probably the result of horizontal gene transfer from fecal bacteria to environmental bacteria. The range of diversity of the tet genes found in animal reservoirs and particularly at the end of the animal digestive tract is wider than for those found in soil and water, indicating that genes encoding resistance do not have the same probability of transmission to the environment. Runoff water might be an important dissemination agent for the most frequent tet genes in this region; however, the impact of infiltrated wastewaters on groundwater appears to be lower, although it is necessary to include more ground water sampling sites to reach a conclusion.

\section{ACKNOWLEDGMENTS}

This work was supported by the Administrative Department of Science, Technology and Innovation of the Republic of Colombia (COLCIENCIAS), Project No. 460-2008, and the University Jorge Tadeo Lozano. We thank the Colombian Corporation for Agricultural Research (Corpoica), Ernesto Guerra, Fabio Reina, Salvador Rincon, Rafael Reina, and Mauricio Sandoval for allowing us to collect samples on their dairy cattle farms. The authors also like to thank Andrés León for helping in sample collection and PCR experiments. We declare that this project has The Permit for Scientific Research in Biodiversity (No. 9, December 5, 2008) and an Agreement for Access to Genetic Resources from the Scientific Interest Free of Trade Interest (No. 24) issued by the Ministry of Environment, Housing, and Territorial Development of the Republic of Colombia.

Aminov, R. I., and Mackie, R. I. (2007). Evolution and ecology of antibiotic resistance genes. FEMS Microbiol. Lett. 271, 147-161.

Binh, C. T. T., Heuer, H., Kaupenjohann, M., and Smalla, K. (2008). Piggery manure used for soil fertilization is a reservoir for transferable antibiotic resistance plasmids. FEMS Microbiol. Ecol. 66, 25-37.

Blake, D. P., Humphry, R. W., Scott, K. P., Hillman, K., Fenlon, D. R., and Low, J. C. (2003). Influence of tetracycline exposure on tetracycline resistance and carriage of tetracycline resistance genes within commensal populations. J. Appl. Microbiol. 94, 1087-1097.

Bryan, A., Shapir, N., and Sadowsky, M. J. (2004). Frequency and distribution of tetracycline resistance genes in genetically diverse, nonselected, and nonclinical Escherichia coli strains isolated from diverse human and animal sources. Appl. Environ. Microbiol. 70, 2503-2507.
Calabria de Araujo, J., and Schneider, R. P. (2008). DGGE with genomic DNA: suitable for detection of numerically important organisms but not for identification of the most abundant organisms. Water Res. 42, 5002-5010.

Callaway, T. R., Dowd, S. E., Edrington, T. S., Anderson, R. C., Krueger, N., Bauer, N., Kononoff, P. J., and Nisbet, D. J. (2011). Evaluation of bacterial diversity in the rumen and feces of cattle fed different levels of dried distillers grains plus solubles using bacterial tag-encoded FLX amplicon pyrosequencing. J. Anim. Sci. 88, 3977-3983.

Campagnolo, L., Jonhson, K., Karpati, A., Rubin, C., Kolpin, D., Meyer, M., Esteban, E., Currier, R., Smith, K., Thu, K., and McGeehin, M. (2002). Antimicrobial residues in animal waste and water resources proximal to large scale swine and poultry feeding operations. Sci. Total Environ. 299, 89-95. 
Chee-Sanford, J. C., Aminov, R. I., Krapac, I. J., Garrigues-Jean-Jean, N., and Mackie, R. J. (2001). Occurrence and diversity of tetracycline resistance genes in lagoons and groundwater underlying two swine production facilities. Appl. Environ. Microbiol. 67, 1494.

Chopra, I., and Roberts, M. (2001). Tetracycline antibiotics: mode of action, applications, molecular biology, and epidemiology of bacterial resistance. Microbiol. Mol. Biol. Rev. 65, 232-260.

Gilliver, M., Bennett, M., Begon, M., Hazel, S., and Hart, C. (1999). Antibiotic resistance found in wild rodents. Nature 401, 233-234.

Götz, A., and Smalla, K. (1997). Manure enhances plasmid mobilization and survival of Pseudomonas putida introduced into field soil. Appl. Environ. Microbiol. 63, 1980-1986.

Heuer, H., Schmitt, H., and Smalla, K. (2011). Antibiotic resistance gene spread due to manure applications on agricultural fields. Curr. Opin. Microbiol. 14, 1-8.

Heuer, H., and Smalla, K. (2007). Manure and sulfadiazine synergistically increased bacterial antibiotic resistance in soil over at least two months. Environ. Microbiol. 9, 657-666.

IDEAM. (2010). Informe Anual sobre el Estado del Medio Ambiente y los Recursos Naturales Renovables en Colombia - Bosques. Bogotá, DC: Instituto de Hidrología, Meteorología y Estudios Ambientales de Colombia.

Knapp, C. W., Schmitt, H., and Smalla, K. (2010). Evidence of increasing antibiotic resistance gene abundances in archived soils since 1940. Environ. Sci. Technol. 44, 580-587.

Kobashi, Y., Hasebe, A., Nishi, M., and Uchiyama, H. (2007). Diversity of tetracycline resistance genes in bacteria isolated from various agricultural environments. Microbes Environ. 22, 44-51.

Kobayashi, T., Suehiro, F., Tuyen, B. C., and Suzuki, S. (2007). Distribution and diversity of tetracycline resistance genes encoding ribosomal protection proteins in
Mekong River sediments in Vietnam. FEMS Microbiol. Ecol. 59, 729-737.

Kocherginskaya, S., Aminov, R. I., and White, B. (2001). Analysis of the rumen bacterial diversity under two different diet conditions using denaturing gradient gel electrophoresis, random sequencing, and statistical ecology approaches. Anaerobe 7, 119-134.

Koike, S., Krapad, I. G., Oliver, H. D., Yanarel, A. C., Chee-Sanford, J. C., Aminov, R. I., and Mackie, R. I. (2007). Monitoring and source tracking of tetracycline resistance genes in lagoons and groundwater adjacent to swine production facilities over a 3 year period. Appl. Environ. Microbiol. 73, 4813-4823.

Loffler, F. E., Sung, Q. J., Li, J., and Tiedje, J. M. (2000). 16S rRNA gene based detection of tetrachloroethene dechlorinating Desulfuromonas and Dehalococcoides species. Appl. Environ. Microbiol. 66, 1369-1374.

Martinez, J. L. (2009). The role of natural environments in the evolution of resistance traits in pathogenic bacteria. Proc. Biol. Sci. 276, 2521-2530.

Michelland, R. J., Monteils, V., Zened, A., Combes, S., Cauquil, L., Gidenne, T., Hamelin, J., and Fortun-Lamothe, L. (2009). Spatial and temporal variations of the bacterial community in the bovine digestive tract. J. Appl. Microbiol. 107, 1642-1650.

Nikolich, M. P., Shoemaker, N. B., and Salyers, A. A. (1992). A bacteroides tetracycline resistance gene represents a new class of ribosome protection tetracycline resistance. Antimicrob. Agents Chemother. 36, 1005-1012.

Oficina Regional de la FAO para América Latina y el Caribe (FAO). (2008). Ayudando a desarrollar una ganadería sustentable en América Latina y el Caribe. Lecciones a Partir de Casos Exitosos. Santiago: Organización de las Naciones Unidas Para la Agricultura y la Alimentación.

Patterson, J. A., Colangelli, R., Spigaglia, P., and Scott, K. P. (2007). Distribution of specific tetracycline and erythromycin resistance genes in environmental samples assessed by microarray detection. Environ. Microbiol. 9, 703-715.

Peak, N., Knapp, C. W., Yang, R. K., Hanfelt, M. M., Smith, M. S., Aga, D. S., and Graham, D. W. (2007). Abundance of six tetracycline resistance genes in wastewater lagoons at cattle feedlots with different antibiotic use strategies. Environ. Microbiol. 9, 143-151.

Rahman, H. M., Sakamoto, K. Q., Nonaka, L., and Suzuki, S. (2008). Occurrence and diversity of tetracycline resistance gene tet $(\mathrm{M})$ in enteric bacteria of Antarctic Adélie penguin. J. Antimicrob. Chemother. 62, 627-628.

Roberts, M. C. (2005). "Tetracycline resistance due to ribosomal protections proteins," in Frontiers In Antimicrobial Resistance, eds D. G. White, M. N. Alekshun, and P. F. McDermott (Washington, DC: ASM Press), 19-28.

Sawant, A. A., Narasimha, V. H., Straley, B. A., Donaldson, S. C., Love, B., Knabel, S. J., and Jayarao, B. M. (2007). Antimicrobial resistant enteric bacteria from dairy cattle. Appl. Environ. Microbiol. 73, 156-163.

Schwarz, S., Cloeckaert, A., and Roberts, C. (2006). "Mechanisms and spread of bacterial resistance to antimicrobial agents," in Antimicrobial Resistance in Bacteria of Animal Origin, ed. F. M. Aareestrup (Washington, DC: ASM Press), 73-98.

Sengelov, G., Agerso, Y., HallingSorencen, B., Beloda, S. B., Anderdsen, J. S., and Jensen, L. B. (2003). Bacterial antibiotic resistance levels in Danish farmland as a result of treatment with pig manure slurry. Environ. Int. 28, 587-595.

Steinfeld, H., Gerber, P., Wassernaar, T., Castel, V., Rosales, M., and deb Hann, C. (2006). Livestock's Long ShadowEnvironmental Issues and Options. Rome: LEAD/FAO.

Tao, R., Ying, G., Su, H. C., Zou, H. W., and Sidhu, J. P. S. (2010). Detection of antibiotic resistance and tetracycline resistance genes in Enterobacteriaceae isolated from Pearl rivers in South China. Environ. Pollut. 158, 2101-2109. van den Bogaard, A. E., and Stobberingh, E. E. (2000). Epidemiology of resistance to antibiotics links between animal and humans. Int. J. Antimicrob. Agents 14, 327-335.

Winckler, C., and Grafe, A. (2001). Use of veterinary drugs in intensive animal production facilities evidence of persistence of tetracycline in pig slurry. J. Soils Sediments 1, 66-70.

Witte, W. (2000). Ecological impact of antibiotic use in animals on different complex microflora environment. Int. J. Antimicrob. Agents 14, 321-325.

Yang, H., Byelashov, O. A., Geornaras, I., Goodridge, L. D., Nightingale, K. K., Belk, K. E., Smith, G. C., and Sofos, J. N. (2010). Presence of antibiotic resistant commensal bacteria in samples from agricultural, city, and national park environments evaluated by standard culture and real time PCR methods. Can. J. Microbiol. 56, 761-770.

Conflict of Interest Statement: The authors declare that the research was conducted in the absence of any commercial or financial relationships that could be construed as a potential conflict of interest.

Received: 04 September 2011; accepted: 29 November 2011; published online: 14 December 2011.

Citation: Santamaría J, López L and Soto CY (2011) Detection and diversity evaluation of tetracycline resistance genes in grassland-based production systems in Colombia, South America. Front. Microbio. 2:252. doi: 10.3389/fmicb.2011.00252

This article was submitted to Frontiers in Antimicrobials, Resistance and Chemotherapy, a specialty of Frontiers in Microbiology.

Copyright (C) 2011 Santamaría, López and Soto. This is an open-access article distributed under the terms of the Creative Commons Attribution Non Commercial License, which permits noncommercial use, distribution, and reproduction in other forums, provided the original authors and source are credited. 